\title{
Ciliate community structure in two South Andean lakes: the effect of lake water on Ophrydium naumanni distribution
}

\author{
Beatriz E. Modenutti*, Esteban G. Balseiro, Claudia P. Queimaliños \\ Lab. Limnology, Centro Regional Universitario Bariloche, Universidad Nacional del Comahue, Unidad Postal Universidad, \\ 8400, Bariloche, Río Negro, Argentina
}

\begin{abstract}
Planktonic ciliates were examined during a spring-summer period (November 1998 to April 1999) in 2 South Andean lakes in Argentina, with different dissolved organic carbon (DOC) and nutrient concentrations. Lake Moreno Oeste is a deep warm monomictic lake $\left(Z_{\max }=90 \mathrm{~m}\right)$, while Lake Morenito is shallower $\left(Z_{\max }=12 \mathrm{~m}\right.$ ) and polymictic. Sampling was performed in a mid-lake station, where vertical profiles of temperature, light, and chlorophyll a concentration were measured in situ. In addition, DOC and phosphorus concentrations were determined, and samples for bacteria, phytoplankton and ciliate enumeration were taken along the water columns. Lake Morenito presented DOC and phosphorus concentrations 3-fold higher than those of Lake Moreno Oeste. Two different ciliate assemblages were present. Lake Moreno Oeste was dominated by the large mixotrophic ciliate Ophrydium naumanni, which was absent in Lake Morenito. In order to test $O$. naumanni water dependence, a series of laboratory experiments were performed during the sampling season. The experiments consisted of the incubation of the ciliate in filtered water from both lakes and the subsequent analysis of growth rates in each treatment. In addition, experiments with Moreno Oeste lake water with a 4 -fold increased phosphorus concentration (addition of MBL culture medium) were conducted. The incubation of $O$. naumanni in Lake Morenito water led to highly negative growth rates of the ciliate. Results showed that the addition of nutrients did not cause significant differences in the growth rates.
\end{abstract}

KEY WORDS: Planktonic ciliates - Mixotrophy · Ultraoligotrophic lakes · Ophrydium naumanni Mixotrophic ciliates

\section{INTRODUCTION}

Over the last few decades studies have stressed the key role that ciliates may play in aquatic microbial food webs in lakes (Beaver \& Crisman 1989, Müller et al. 1991, Amblard et al. 1993, Macek et al. 1996). These studies have revealed that ciliate communities in the pelagic are composed of a great number of species with different feeding strategies, ranging from phagotrophic ingestion of particles to photosynthetic fixation of organic carbon (Jones 1994). The photosynthetic capability of heterotrophic organisms like ciliates can be acquired by sequestration of chloroplasts from ingested prey or by possession of photo-

\footnotetext{
•E-mail: bmode@crub.uncoma.edu.ar
}

synthetic cells as endosymbionts (Reisser et al. 1985, Stoecker \& Silver 1987, Perris et al. 1994). This mixed nutrition, termed mixotrophy, combines autotrophic and heterotrophic nutrition in a single individual. In this sense, mixotrophy can be viewed as an adaptive strategy that provides greater flexibility in the planktonic environment (Jones 1994), since it may improve access to scarce nutrients (Nygaard \& Tobiesen 1993). This feeding mode should provide a strong advantage in oligotrophic environments (Jones 1994); therefore, mixotrophic ciliates appear especially favoured in oligotrophic waters, where a close nutrient cycle within the symbiotic association would confer advantages to both members of the association (Fenchel 1987). In Andean lakes a distinctive assemblage of large mixotrophic ciliates $(>80 \mu \mathrm{m})$ constituted by the peritrich Ophrydium naumanni Pejler and the heterotrich Sten- 
tor araucanus Foissner \& Wölfl has been previously reported (Modenutti 1997). The large size of these 2 species (O. naumanni: $112 \times 14 \mu \mathrm{m}$ and $S$ araucanus: $230 \times 130 \mu \mathrm{m}$ ) would confer a particular feature to this ciliate assemblage since metabolism, growth rates, etc. are dependent on size. These 2 species have been found only in large and deep ultraoligotrophic lakes (Area $>5 \mathrm{~km}^{2}, Z_{\max } \approx 100 \mathrm{~m}$ ), where they develop large populations. Based on a data set from 18 Andean lakes, Modenutti (1997) indicated that these mixotrophic ciliates were restricted to lakes with low dissolved organic carbon (DOC) concentrations $\left(<0.6 \mathrm{mg} \mathrm{Cl}^{-1}\right)$. Recently, vertical distribution of $O$. naumanni was studied in detail and a deep chlorophyll maximum caused by this ciliate was described (Queimaliños et al. 1999). In addition, laboratory experiments determined a strong dependence of $O$. naumanni on light (Queimaliños et al. 1999).

In this study we tested the dissolved organic fraction as a factor limiting Ophrydium naumanni distribution. We performed a comparative analysis in 2 adjacent lakes from the same basin, Moreno Oeste and Morenito. These 2 lakes are not unique, since the South Andes region has many large, deep lakes of low productivity like Lake Moreno Oeste, and many smaller, shallower and more productive environments like Lake Morenito (Morris et al. 1995). In all these lakes the presence or absence of large mixotrophic ciliates like $O$. naumanni follows the same pattern as the studied lakes (Moreno Oeste and Morenito) (Modenutti 1997. Modenutti et al. 1998a,b). Lakes Moreno Oeste and Morenito have different limnological features, including DOC and total dissolved phosphorus (TDP) concentrations, and different ciliate communities, with the absence of large mixotrophic ciliates, like $O$. naumanni, in the smaller Lake Morenito. However, both lakes have the same metazooplankton constitution without differences in invertebrate predators; therefore no differential impacts in top-down effect could be expected. In addition, through laboratory experiments, we analysed growth rates of $O$. naumanni reared in treatments with Moreno Oeste and Morenito filtered lake water.

\section{MATERIALS AND METHODS}

Study area. The studied lakes, Lake Moreno Oeste (41.5 $5^{\prime} \mathrm{S}, 71^{\circ} 33^{\prime} \mathrm{W} ; 758 \mathrm{~m}$ above sea level [a.s.l.]) and Lake Morenito $\left(41^{\circ} 3^{\prime} \mathrm{S}, 71^{\circ} 30^{\prime} \mathrm{W} ; 758 \mathrm{~m}\right.$ a.s.l.), both belong to the Nahuel Huapi System (Patagonia, Argentina) (Fig. 1). The area is included in the Nahuel Huapi National Park and is free from industrial and human impacts. These adjacent lakes constituted a single lake until 1960, when a division was artificially created between them by the construction of a dirt road. Lake Morenito, which was a small bay of the original lake, became delimited as an independent body of water, except for once a year, when the surface level of the basin is high and a shallow connection is reestablished. It has a surface area of $0.83 \mathrm{~km}^{2}$, a maximum depth of $12 \mathrm{~m}$, and a rather high transparency (Secchi depth: $5 \mathrm{~m}$ ). The thermal regime is continuous cold polymictic, since it occasionally freezes $\left(0^{\circ} \mathrm{C}\right.$ at the surface and $3^{\circ} \mathrm{C}$ at the bottom) during harsh winters (July and August). During the major part of the year, temperature is homogeneously distributed through the water column. In spring and autumn the temperature ranges from 10 to $15^{\circ} \mathrm{C}$, while in summer it reaches $22^{\circ} \mathrm{C}$ (January and February).

Iñ Cuntrast, Lake Mivi enu Oesie is a warm monomictic ultraoligotrophic deep lake, with a particularly high transparency (Secchi depth: $20 \mathrm{~m}$ ). It has a surface area of $6 \mathrm{~km}^{2}$ and a maximum depth of $90 \mathrm{~m}$. The lake remains thermally stratified from late November through April (spring-summer months), During the period of direct stratification the lake develops a marked thermocline around $30 \mathrm{~m}$ depth, with 11 to $18^{\circ} \mathrm{C}$ in the epilimnion and $7^{\circ} \mathrm{C}$ in the hypolimnion. The mixed period occurs during late autumn and winter months and the temperature is $7^{\circ} \mathrm{C}$ throughout the water column. Dissolved oxygen concentration remains at saturation levels throughout the water column. During thermal stratification in Lake Moreno Oeste, oxygen vertical distribution describes an orthograde curve, typical of an unproductive lake. On the contrary, no distinct differences in oxygen vertical distribution were observed in Lake Morenito. Both lakes always presented very low conductivity values $(\sim 60 \mu \mathrm{S}$ $\left.\mathrm{cm}^{-1}\right)$.

Field study. The study was conducted in a central sampling point located at the deepest part of each basin (Lake Moreno Oeste: $z=70 \mathrm{~m}$; Lake Morenito: $z=12 \mathrm{~m}$ ) (Fig. 1).

During southern summer, between November 1998 and April 1999, both lakes were sampled on 9 occasions. All samplings were carried out at midday $1 \mathrm{~h}$ before astronomic noon. Temperature and light (photosynthetically active radiation, PAR, 400 to $700 \mathrm{~nm}$ ) profiles were measured from 0 to $60 \mathrm{~m}$ (Moreno Oeste) and from 0 to $10 \mathrm{~m}$ (Morenito) with a PUV 500B submersible radiometer (Biospherical Instruments). In situ chlorophyll a profiles were determined on the basis of the natural fluorescence measured by the PUV 500B (PUV 683), and oxygen vertical distribution with an oxymeter (YSI). Concurrently, water samples (2 replicates) were taken from 0 to $52 \mathrm{~m}$ at $4 \mathrm{~m}$ intervals from Lake Moreno Oeste and from 0 to $8 \mathrm{~m}$ each $2 \mathrm{~m}$ interval from Lake Morenito. The samples were obtained with a Schindler-Patalas trap of 121 and this volume 


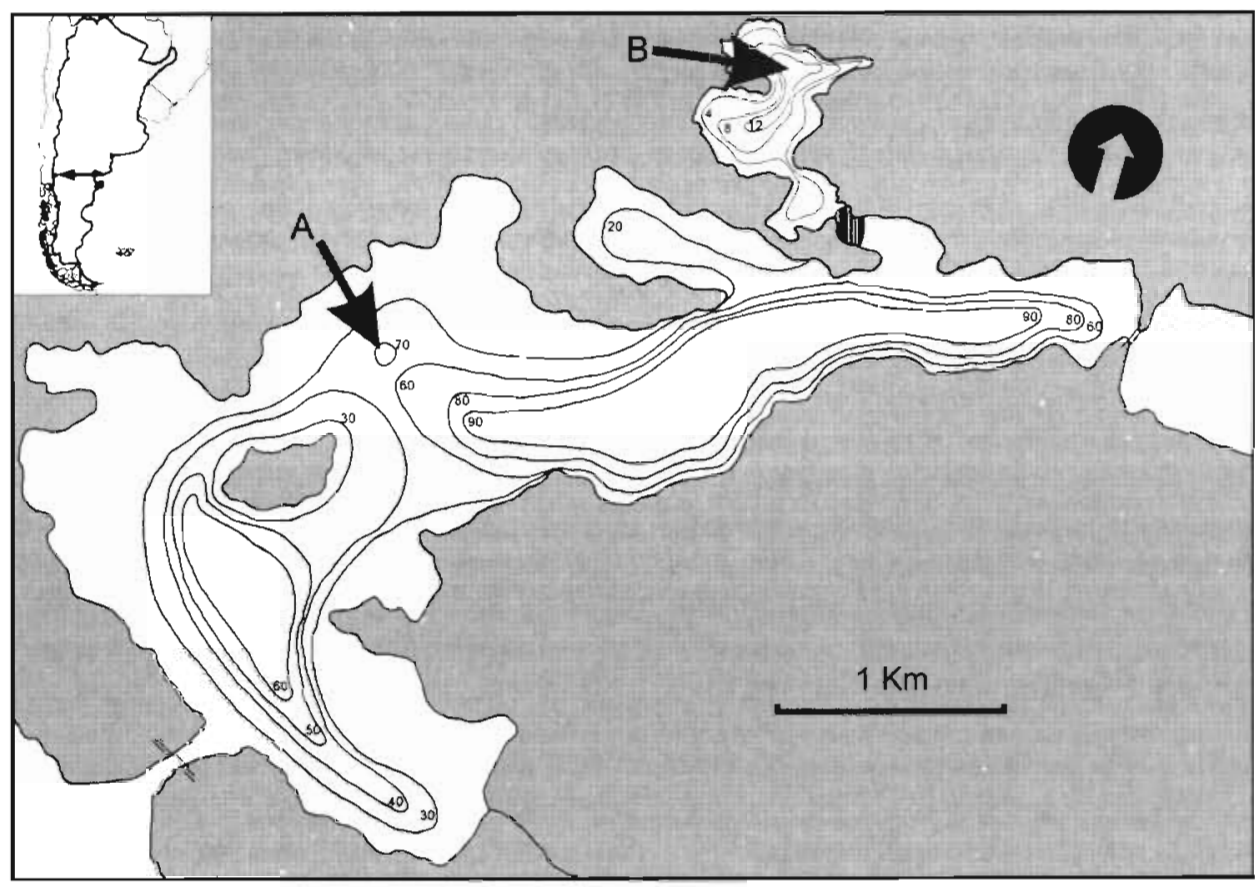

Fig. 1. Study area with sampling locations (A) Lake Moreno Oeste and (B) Lake Morenito

was distributed in different sampling bottles for the different purposes.

Total phosphorus (TP) was determined on $150 \mathrm{ml}$ of unfiltered lake water and the same volume of filtered water (GF/C) was used for TDP. The samples were digested with potassium persulphate at $125^{\circ} \mathrm{C}$ at $1.5 \mathrm{~atm}$ for $1 \mathrm{~h}$. The concentrations were analysed through the ascorbate-reduced molybdenum method (APHA 1985). DOC was estimated by spectrophotometry through a regression model based on Morris et al. (1995). Previously, a spectrophotometric intercalibration was performed against a Shimadzu TOC 5000 DOC determination (D. Morris pers. comm.).

Samples for total bacteria enumeration were fixed with formaldehyde (final concentration $2 \% \mathrm{v} / \mathrm{v}$ ) and stained with fluorochrome 4',6-diamidino-2-phenylindole (DAPI; final concentration $0.2 \% \mathrm{w} / \mathrm{v}$ ) according to Porter \& Feig (1980). Counting was performed on black membrane filters (Poretics, $0.2 \mu \mathrm{m}$ pore size) at $1000 \times$ in an Olympus BX50 epifluorescence microscope using UV light (U-MWU filter). A minimum of 1000 bacteria per sample was counted and the quantification was carried out within 2 wk following sampling. Samples were stored in darkness and refrigerated.

Samples for phytoplankton and ciliates were fixed with acid Lugol's solution and were quantified with an inverted microscope using $50 \mathrm{ml}$ Utermöhl chambers. Phytoplankton enumeration was performed following the Utermöhl technique at $400 \times$. Ciliate quantification was carried out scanning the entire surface of the chamber at $200 \times$. Ciliate species identification was based on Foissner et al. (1991, 1992, 1994, 1995) and Foissner \& Wölfl (1994) and Pejler (1962).

Experimental study. In order to test Ophrydium naumanni water dependence, a series of laboratory experiments were performed during the sampling season. The experiments consisted of the incubation of the ciliate in both Moreno Oeste and Lake Morenito water, filtered through GF/C or a membrane filter of $0.45 \mu \mathrm{m}$ pore size. The water used in the experiments was freshly collected the same day of experimentation at $20 \mathrm{~m}$ (Moreno Oeste) and $6 \mathrm{~m}$ depth (Morenito). The experiments lasted between 3 and $8 \mathrm{~d}$ and were conducted in a growth chamber at $14^{\circ} \mathrm{C}$ and a $14: 10 \mathrm{~h}$ light:dark photoperiod; light intensity inside the chamber was $39.0 \mu \mathrm{E} \mathrm{m}^{-2} \mathrm{~s}^{-1}$. These conditions closely resemble the summer epilimnion of Lake Moreno Oeste at $20 \mathrm{~m}$ depth and were tested in previous experiments (Queimaliños et al. 1999). The experiments were run in $10 \mathrm{ml}$ test tubes that were rotated on a turntable at $2 \mathrm{rpm}$. Before starting the experiments all vessels and test tubes were carefully cleaned and sterilised $\left(121^{\circ} \mathrm{C}, 1 \mathrm{~atm}, 20 \mathrm{~min}\right)$. The specimens used in the experiments were collected at $20 \mathrm{~m}$ depth from Lake Moreno Oeste the day before and maintained in the laboratory under experimental conditions (light in addition to temperature). Individuals were transferred 
to experimental vessels and counted with a sterilised pipette under a stereomicroscope. The experimental design consisted of 2 to 3 treatments with 5 replicates each. Experiments were started with 5 individuals per replicate. An experimental summary is shown in Table 1. Expts 4 and 8 were run to test if the effect of lake water source was stable in time. In this case, water was replaced by freshly filtered lake water on Days 3 (Expt 4) and 4 (Expt 8).

Results of the experiments were expressed as growth rate $(r)$ :

$$
r=\frac{\ln N_{t}-\ln N_{0}}{t}
$$

where $N_{0}=$ number of individuals at the beginning of the experiment, $N_{t}=$ number of individuals at the end of the experiment, and $t$ - time of experimentation.

The filtered water (membrane $0.45 \mu \mathrm{m}$ or $\mathrm{GF} / \mathrm{C}$ ) used for the experiments was examined in order to determine DOC and phosphorus and bacterial concentrations. Results showed that there were no differences in the dissolved fraction concentration (DOC and phosphorus) between water filtered through $\mathrm{GF} / \mathrm{C}$ and through $0.45 \mu \mathrm{m}$ membrane filter. In contrast, bacterial number was reduced to $80 \%$ when the water was filtered through $\mathrm{GF} / \mathrm{C}$, while there was a drastic reduction (to less than $20 \%$ ) when the $0.45 \mu \mathrm{m}$ membrane filter was used. In neither case were flagellate cells recorded.

Similar laboratory experiments were run in order to test the effect of increased nutrient concentration. Treatments consisted of Lake Moreno Oeste water filtered through a membrane filter of $0.45 \mu \mathrm{m}$ pore size and the addition of sufficient MBL culture medium
(Nichols 1973) to raise the phosphorus concentration to $10 \mu \mathrm{g} \mathrm{l}^{-1}$ (close to the phosphorus concentration of Lake Morenito). Controls consisted of Moreno Oeste filtered lake water without the addition of $\mathrm{MBL}$ medium ( $\mathrm{P}$ concentration $2.5 \mu \mathrm{g} \mathrm{l}^{-1}$ ). Both the treatment and control were run in 5 replicates; all experiments lasted for $2 \mathrm{~d}$. Results were also expressed as Ophrydium naumanni growth rates.

Experimental results were compared through a $t$ test, except in Expt 5 (Table 1) where ANOVA was applied. In all statistical analyses normality and homoscedasticity were tested.

\section{RESULTS}

Although both lakes belong to the same watershed they differ markedly in their limnological features. During the study period Lake Moreno Oeste developed a direct stratification with a marked thermocline around $30 \mathrm{~m}$ depth; temperatures ranged from 15 to $17^{\circ} \mathrm{C}$ in the epilimnion and $7^{\circ} \mathrm{C}$ in the hypolimnion. In contrast, no thermal stratification was observed in Lake Morenito. Temperature was always homogeneously distributed through the water column, ranging from $15^{\circ} \mathrm{C}$ (November, March and April) up to $21^{\circ} \mathrm{C}$ in the mid-summer months (January and February). Dissolved oxygen concentration ( 8 to $11 \mathrm{mg} \mathrm{l}^{-1}$ ) remained at saturation levels all through the water column. In Lake Moreno Oeste, oxygen vertical distribution described an orthograde curve, whereas no distinct differences in oxygen vertical distribution were observed in Lake Morenito.

Table 1. Experimental design of Ophrydium naumanni growth rates under the different water treatment tests. End abundances are mean $\pm \mathrm{SE}$

\begin{tabular}{|c|c|c|c|c|c|c|}
\hline Expt & Lake water & Filter & $\begin{array}{l}\text { Start date } \\
(\mathrm{d} / \mathrm{mo} / \mathrm{yr})\end{array}$ & $\begin{array}{l}\text { End date } \\
(\mathrm{d} / \mathrm{mo} / \mathrm{yr})\end{array}$ & $\begin{array}{l}\text { Duration of incubation } \\
\text { (d) }\end{array}$ & End abundance \\
\hline \multirow[t]{2}{*}{1} & Moreno & $0.45 \mu \mathrm{m}$ & $17 / 11 / 98$ & $20 / 11 / 98$ & 3 & $6.6 \pm 0.66$ \\
\hline & Morenito & $0.45 \mu \mathrm{m}$ & & & & $3.6 \pm 0.97$ \\
\hline \multirow[t]{2}{*}{2} & Moreno & $0.45 \mu \mathrm{m}$ & $20 / 11 / 98$ & $23 / 11 / 98$ & 3 & $7.2 \pm 1.28$ \\
\hline & Morenito & $0.45 \mu \mathrm{m}$ & & & & $3.0 \pm 0.57$ \\
\hline \multirow[t]{2}{*}{3} & Moreno & $0.45 \mu \mathrm{m}$ & $09 / 04 / 99$ & $12 / 04 / 99$ & 3 & $6.6 \pm 0.51$ \\
\hline & Morenito & $0.45 \mu \mathrm{m}$ & & & & $3.6 \pm 0.51$ \\
\hline \multirow[t]{2}{*}{4} & Moreno & $0.45 \mu \mathrm{m}$ & $09 / 04 / 99$ & $15 / 03 / 99$ & 6 & $7.4 \pm 0.81$ \\
\hline & Morenito & $0.45 \mu \mathrm{m}$ & & & & $3.0 \pm 0.70$ \\
\hline \multirow[t]{3}{*}{5} & Moreno & $\mathrm{GF} / \mathrm{C}$ & $18 / 01 / 99$ & $22 / 01 / 99$ & 4 & $6.0 \pm 0.44$ \\
\hline & Morenito & $G F / C$ & & & & $2.3 \pm 0.88$ \\
\hline & Morenito & $0.45 \mu \mathrm{m}$ & & & & $2.6 \pm 0.88$ \\
\hline \multirow[t]{2}{*}{6} & Moreno & $\mathrm{GF} / \mathrm{C}$ & $26 / 01 / 99$ & $29 / 01 / 99$ & 3 & $4.6 \pm 0.51$ \\
\hline & Morenito & $\mathrm{GF} / \mathrm{C}$ & & & & $2.2 \pm 0.37$ \\
\hline \multirow[t]{2}{*}{7} & Moreno & $\mathrm{GF} / \mathrm{C}$ & $11 / 03 / 99$ & $15 / 03 / 99$ & 4 & $5.8 \pm 0.58$ \\
\hline & Morenito & $\mathrm{GF} / \mathrm{C}$ & & & & $3.4 \pm 0.24$ \\
\hline \multirow[t]{2}{*}{8} & Moreno & $\mathrm{GF} / \mathrm{C}$ & $11 / 03 / 99$ & $19 / 03 / 99$ & 8 & $6.4 \pm 0.92$ \\
\hline & Morenito & $\mathrm{GF} / \mathrm{C}$ & & & & $3.2 \pm 0.86$ \\
\hline
\end{tabular}


The diffuse extinction coefficients $\left(K_{d}\right)$ were very different in the 2 studied lakes. In Lake Moreno Oeste the obtained values were low and fairly constant, varying between 0.121 and $0.154 \mathrm{~m}^{-1}$ (Table 2). In contrast, Lake Morenito is less transparent since the registered $K_{\mathrm{d}}$ values were higher, varying between 0.335 and $0.397 \mathrm{~m}^{-1}$ (Table 2).

The values of DOC concentration in Lake Moreno Oeste were low, fluctuating around or less than $0.6 \mathrm{mg}$ $\mathrm{l}^{-1}$, and no remarkable shifts were noted down the water column (Fig. 2a). These values are consistent with those previously obtained through direct DOC measurements performed by D. Morris (pers. comm.). On the other hand, Lake Morenito showed a higher DOC concentration $\left(\sim 2.0 \mathrm{mg} \mathrm{l}^{-1}\right)$ with a slight increase towards the bottom (Fig. 2a). The registered values were always at least 3 times higher than those from Lake Moreno Oeste.

Phosphorus concentrations (TDP and TP) in Lake Moreno Oeste were always very low with no remarkable differences along the water column (Fig. 2b). In contrast, in Lake Morenito the values were considerably higher and both TP and TDP slightly increased towards the bottom (Fig. 2b), more than 3-fold compared to Lake Moreno Oeste.

Total bacteria followed the same pattern, increasing their abundance in Lake Morenito. In this water body the maximum density attained was $4 \times 10^{6}{\text { cells } \mathrm{ml}^{-1}}^{-1}$ and no remarkable shifts in vertical distribution were observed (Fig. 3a). In the ultraoligotrophic Lake Moreno Oeste total bacteria abundance values were considerably lower (Fig. 3b). Total bacteria reached $2.5 \times 10^{6}$ cells $\mathrm{ml}^{-1}$ at $36 \mathrm{~m}$ depth on only one sampling occasion (March 9), and the other observed values were below $2 \times 10^{6}$ cells $\mathrm{ml}^{-1}$.

Photosynthetic total biomass was measured as chlorophyll a concentration. In Lake Moreno Oeste, epilimnetic chlorophyll a remained very low (less than $0.6 \mathrm{\mu g} \mathrm{l}^{-1}$ ). However, metalimnetic pigment concentra-

Table 2. Light conditions in Lake Moreno Oeste and Lake Morenito on each sampling date. $K_{\mathrm{d}}$ : diffuse extinction coefficient; $Z_{1 \%}$ : depth of $1 \%$ of surface PAR ( 400 to $700 \mathrm{~nm}$ ) irradiance

\begin{tabular}{|lcccc|}
\hline \multirow{2}{*}{$\begin{array}{l}\text { Date } \\
(\mathrm{d} / \mathrm{mo} / \mathrm{yr})\end{array}$} & \multicolumn{2}{c}{ Lake Moreno } & \multicolumn{2}{c|}{ Lake Morenito } \\
& $K_{\mathrm{d}}\left(\mathrm{m}^{-1}\right)$ & $Z_{1 \%}(\mathrm{~m})$ & $K_{\mathrm{d}}\left(\mathrm{m}^{-1}\right)$ & $Z_{1 \%}(\mathrm{~m})$ \\
\hline $16 / 11 / 98$ & 0.121 & 38 & 0.335 & 12 \\
$12 / 12 / 98$ & 0.135 & 34 & 0.346 & 12 \\
$06 / 01 / 99$ & 0.139 & 33 & 0.361 & 12 \\
$14 / 01 / 99$ & 0.141 & 33 & 0.345 & 12 \\
$25 / 01 / 99$ & 0.145 & 32 & 0.387 & 11 \\
$05 / 02 / 99$ & 0.145 & 32 & 0.397 & 11 \\
$19 / 02 / 99$ & 0.154 & 30 & 0.337 & 12 \\
$09 / 03 / 99$ & 0.138 & 33 & 0.372 & 11 \\
$07 / 04 / 99$ & 0.154 & 30 & 0.370 & 11 \\
& & & & \\
\hline
\end{tabular}

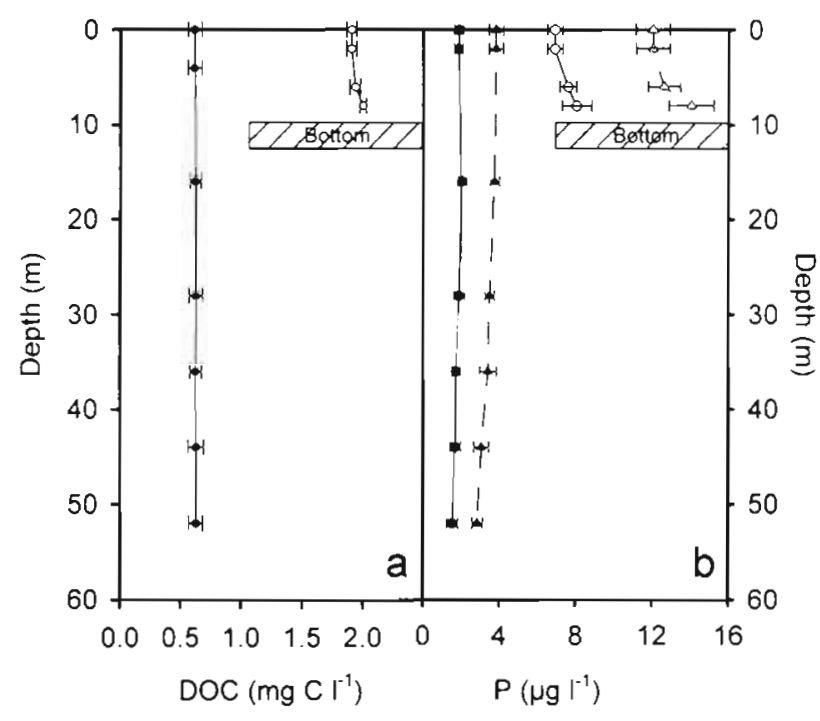

Fig. 2. (a) Dissolved organic carbon (DOC) concentration in the water column during the studied period. (•) Lake Moreno Oeste; (o) Lake Morenito. Horizontal bars indicate standard errors. (b) Total phosphorus (TP) and total dissolved phosphorus (TDP) along the water column during the studied period. $(\boldsymbol{\Lambda}, \Delta)$ TP; $(\bullet, 0)$ TDP (solid symbols: Lake Moreno Oeste; open symbols: Lake Morenito). Horizontal bars indicate standard errors

tion increased up to $1.5 \mathrm{\mu g} \mathrm{l}^{-1}$, producing a clear deep chlorophyll maximum at $30 \mathrm{~m}$ depth, as was reported in a previous study (Queimaliños et al. 1999). Phytoplankton was scarce (on average less than 1000 cells $\mathrm{ml}^{-1}$, reaching up to 1500 cells $\mathrm{ml}^{-1}$ ), with nanoplankton always higher than $90 \%$ and dominated by the nanoflagellate Chrysochromulina parva Lackey. In Lake Morenito, no differential distribution down the water column was observed in chlorophyll a concentrations $\left(-1.2 \mathrm{\mu g} \mathrm{l}^{-1}\right.$ all through the water column). Phytoplankton was more abundant in cell densities (around 2000 cells ml ${ }^{-1}$, reaching 3000 cells ml ${ }^{-1}$ ). In this lake, phytoplankton was also dominated by Chrysochromulina parva, followed by Rhodomonas lacustris (Pascher \& Ruttner) Javornicky.

The ciliate assemblage in Lake Moreno Oeste consisted of the peritrich Ophrydium naumanni, the heterotrich Stentor araucanus, a number of species of oligotrichs (Strobilidium sp. and Strombidium sp.), and the pleurostomatid Paradileptus elephantinus (Svec) as a rare species $(<1 \%$ of total abundance). Therefore, the observed assemblage was characterised by the presence of the 2 species of large ( $>80 \mu \mathrm{m}$ ) mixotrophic ciliates. O. naumanni was the dominant species over almost the 


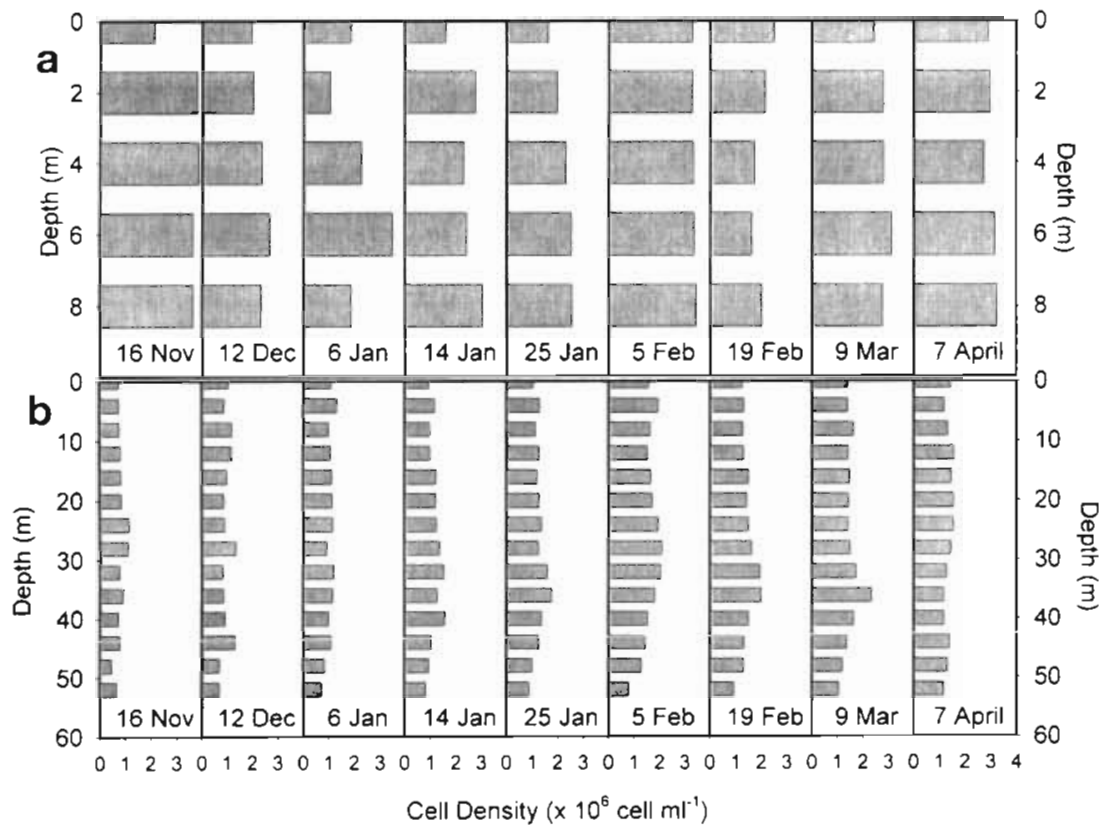

Fig. 3. Total bacterial abundances in the water column during the studied period in (a) Lake Morenito and (b) Lake Moreno Oeste these species are also mixotrophic $i$ in particular, Askenasia sp. and Pelagohalteria sp. have been observed with active chlorophyll when epifluorescence microscopy was applied. In this lake the higher ciliate abundances were found between 2 and 4 $m$ depth on all sampling occasions. The maximum densities were attained in mid-summer (January to February) and $S$. viride and B. planctonicum were found to be the 2 dominant species.

The metazooplankton composition of both lakes was quite similar. The calanoid copepod Bueckelia gracilipes Daday and the cladocerans Ceriodaphnia dubia Richard and Bosmina longirostris (O.F.M.) were the dominant zooplankters. Rotifers were represented by species of Synchaeta, Polyarthra, Keratella and Conochilus. Remarkably, cyclopoid copepods were extremely scarce in both lakes,

total period (Fig. 4), showing an increase in cell density at or below $30 \mathrm{~m}$ depth in November, December and January. This situation had been noted in previous years (1997 to 1998) and was found to be the cause of the deep chlorophyll maximum observed in the lake (Queimaliños et al. 1999). The highest abundance of $O$. naumanni was observed near the limit of the euphotic zone and just below the upper limit of the metalimnion. In contrast, the smaller oligotrichs were more abundant at the upper levels of the epilimnion (Fig. 4).

Remarkably, the large (>80 $\mu \mathrm{m})$ mixotrophic ciliates Ophrydium and Stentor were absent in Lake Morenito where the ciliate assemblage consisted mainly of smaller ciliates $(<50 \mu \mathrm{m})$. The assemblage was dominated by the mixotrophic oligotrich Strombidium viride Stein, over almost the whole period, except on 25 January when the prostomate holotrich $\mathrm{Bal}$ anion planctonicum (Foissner, Oleksiv and Müller) developed a high population density (Fig. 5, note change of scale). In addition, a number of prostomate and mesodiniid holotrichs (Urotricha spp. and Askenasia sp.), other oligotrichs ( $\mathrm{Hal}$ teria sp. and Pelagohalteria sp.) and the pleurostomatid Paradileptus elephantinus were found during the sampling period. Some of and this was indicated as a common feature in the southern hemisphere (Modenutti et al. 1998b).

One of the most striking differences in the ciliate communities between both lakes was the absence of the large mixotrophic ciliates Ophrydium naumanni and Stentor araucanus in Lake Morenito. Since no differential top-down effects can be hypothesised to explain the absence of $O$. naumanni in Lake Morenito, we ran laboratory experiments rearing this species in filtered water from both lakes. Remarkably, the dissolved fraction concentrations of Lake Morenito were 3-fold those of Lake Moreno Oeste; therefore an effect of lake water can be suggested. Experiments revealed a marked dependence of $O$. naumanni on water lake

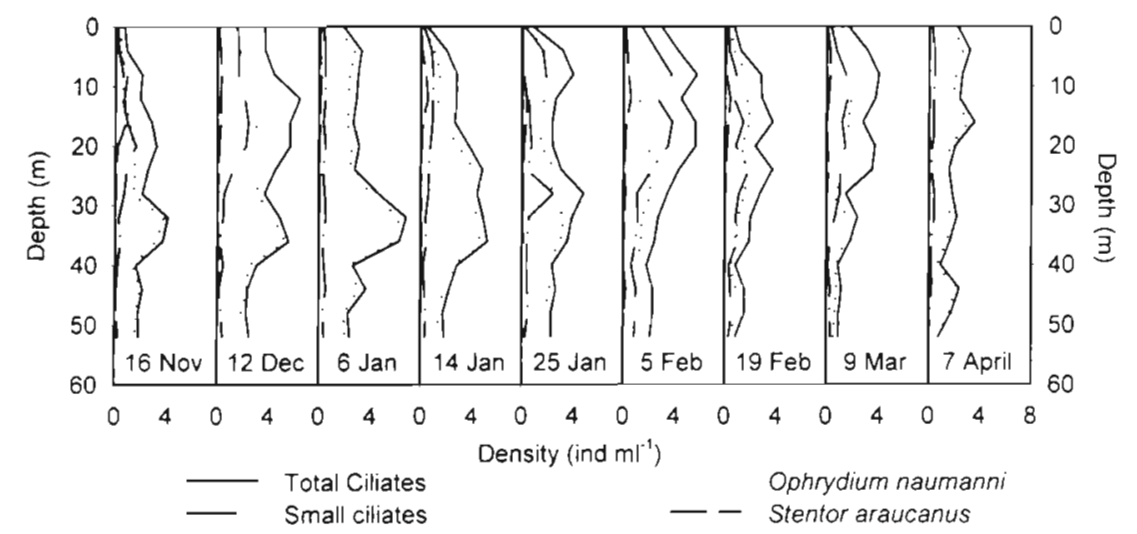

Fig. 4. Total ciliate, Ophrydium naumanni, Stentor araucanus and small ciliates (mainly oligotrichs) abundances in the water column during the studied period in Lake Moreno Oeste 


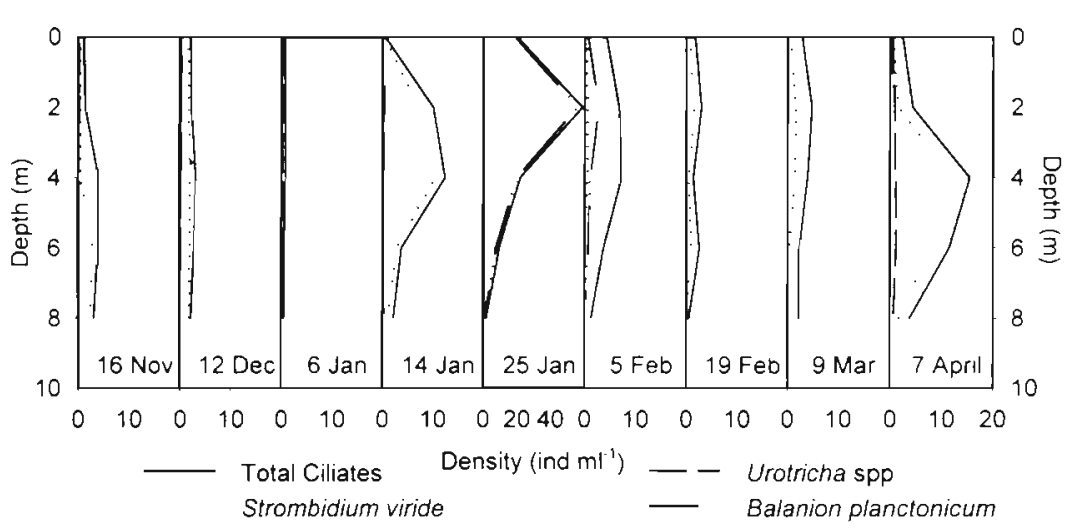

Fig. 5. Total ciliate, Strombidium viride, Urotricha spp. and Balanion planctonicum abundances in the water column during the studied period in Lake Morenito. Note: on 25 January the scale is changed to 0 to 60 cells $\mathrm{ml}^{-1}$
(Fig. 7) results revealed that the addition of phosphorus and other macroand micronutrients did not cause significant differences in the growth rates compared with those of controls $(\mathrm{p}>0.05$ ). In 3 of the experiments (Expts 1 to 3, Fig. 7) we observed positive growth rates in MBL treatments while one experiment (Expt 4, Fig. 7) showed negative growth rates. Controls also presented 3 experiments with positive increases (Fig. 7). However, the treatment and control showed negative growth rates in different experiments.

\section{DISCUSSION}

source (Fig. 6). In all treatments run with Lake Morenito filtered water, filtered through $0.45 \mu \mathrm{m}$ pore membrane filter (Expts 1 to 4 ) or GF/C (Expts 6 to 8), highly negative increase rates of the ciliate were observed (Fig. 6). When compared with equivalent Moreno Oeste lake water, which showed positive growth rates, significant differences $(p<0.05$ or $p<0.01)$ were obtained (Fig. 6). The results attained in Expts 4 and 8, which lasted 6 and $8 \mathrm{~d}$ with a renewal of water on Days 3 and 4 respectively, revealed that the effect of lake water was persistent in time and no acclimatisation of $O$. naumanni to the new condition of lake water was achieved. Expt 5 was run with 3 treatments in order to compare $0.45 \mu \mathrm{m}$ membrane and $\mathrm{GF} / \mathrm{C}$ filtered water of Lake Morenito. The results showed that both Morenito treatments were significantly different $(p<0.05)$ from Moreno Oeste lake water (Fig. 6), while no differences ( $p>0.05$ ) were observed between both treatments of Lake Morenito. These results may indicate no effect of particulate matter on $O$. naumanni increase rates, and therefore the obtained negative increase rates can be attributed to the dissolved fraction.

In the second series of experiments, we tested the effect of the inorganic dissolved fraction (macronutrients and micronutrients included in MBL culture medium) on Ophrydium naumanni growth rates. Treatments consisted of Lake Moreno Oeste filtered water $(0.45 \mu \mathrm{m})$ with a 4-fold increase of phosphorus concentration through the addition of MBL culture medium (Nichols 1973). In all 4 experiments

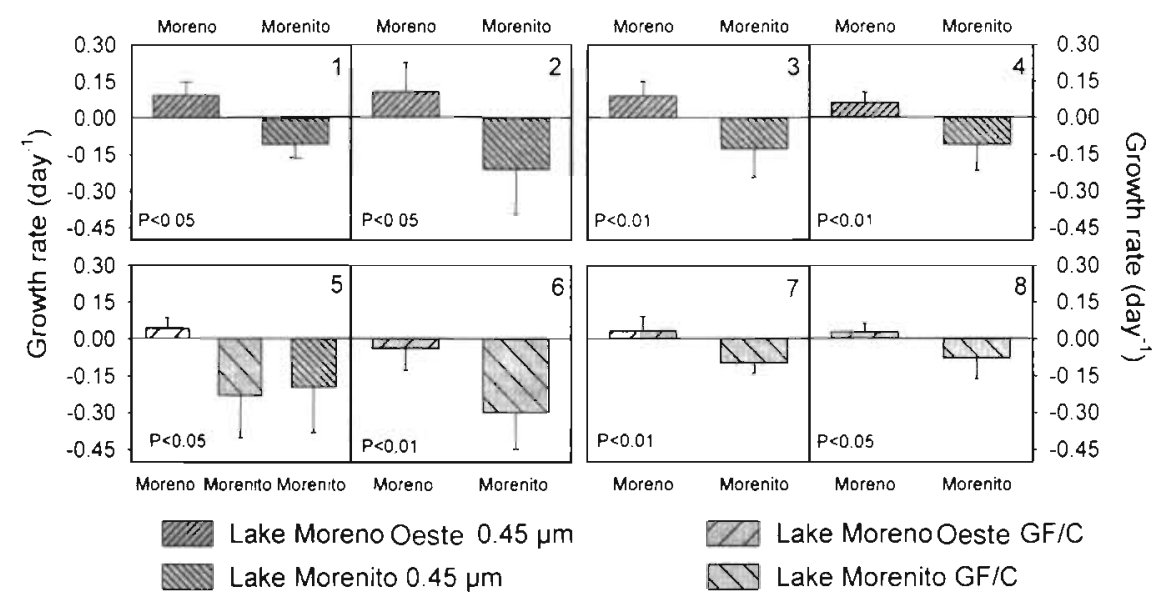

Fig. 6. Growth rates of Ophrydium naumanni in laboratory experiments with Moreno

\footnotetext{
Oeste and Lake Morenito waters. Experimental design as in Table 1
}

Mixotrophy due to the presence of large sized (>80 $\mathrm{mm}$ ) mixotrophic ciliates living autotrophically with internalised symbiotic algae has been found to be important for the plankton of ultraoligotrophic lakes of the southern hemisphere (Foissner \& Wölfl 1994, Wölfl 1995, Modenutti 1997, Modenutti et al. 1998a, Queimaliños et al. 1999). As Geller et al. (1996) stated it is unclear if this kind of mixotrophy (large-sized ciliates) also occurs in ultraoligotrophic lakes of the northern hemisphere. In the ultraoligotrophic Lake Moreno Oeste, Ophrydium naumanni dominated the ciliate assemblage, showing a marked vertical distribution during the early summer months, with higher abundance near 30 m depth (Fig. 4). In previous experiments, this species showed a strong dependence on light since it cannot survive under dark conditions (Queimaliños et al. 1999). 


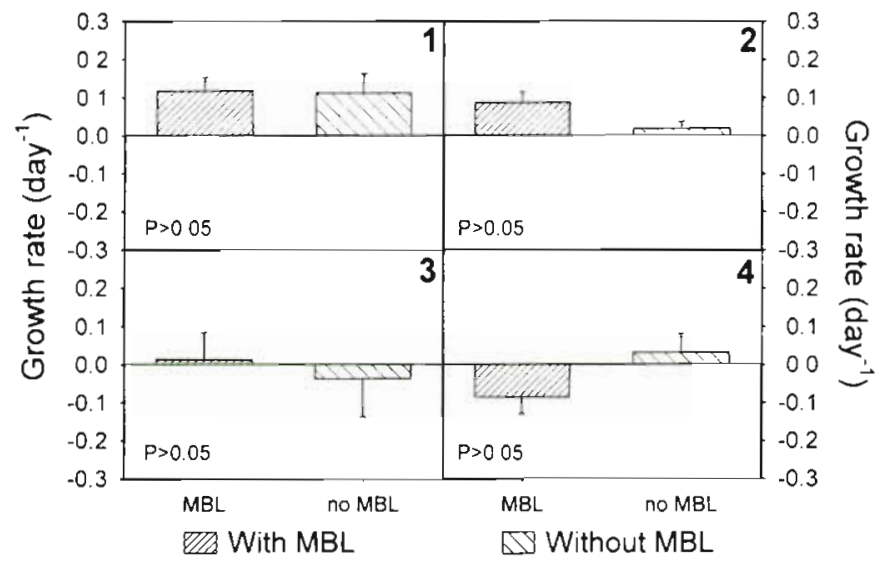

Fig. 7. Growth rates of Ophrydium naumanni in laboratory experiments with Moreno Oeste lake water, with and without the addition of MBL culture medium

The data set presented here showed that although the adjacent lakes constituted a unique body of water until 1960, the limnological features of both systems now differ markedly (Table 2, Fig. 2). Probably, these differences bring out the failure of Ophrydium naumanni in Lake Morenito. Since this species is strongly dependent on light (disappearing under dark conditions after 96 h; Queimaliños et al. 1999) it could be surmised that light conditions required by $O$. naumanni are not achieved in the smaller and shallower Lake Morenito. However, light intensities of $1 \%$ are located at 11 to $12 \mathrm{~m}$ depth in this lake (Table 2). On the other hand, $O$. naumanni does appear at higher light intensities than $1 \%$ in Lake Moreno Oeste (Table 2, Fig. 4). This means that light conditions of the upper $30 \mathrm{~m}$ of Lake Moreno Oeste are found in Lake Morenito. It seems that, although $O$. naumanni depends highly on light, this factor is not responsible for the difference between both lakes in the presence of this mixotrophic ciliate.

Another possiblity is that negative growth rates leading to disappearance may be due to predator-induced mortality. However, as the lakes do not differ either in crustacean planktonic species or in rotifer ones, we could not expect this top-down control.

The results of our experiments supported the idea that the dissolved fraction plays a role in Ophrydium naumanni distribution. In all treatments with Lake Morenito water a significant negative increase rate was obtained (Fig. 6). Also, the obtained results support the data of Modenutti (1997), who indicated that this large mixotrophic ciliate was restricted to lakes with low DOC concentration, less than $0.6 \mathrm{mg} \mathrm{C} \mathrm{I}^{-1}$. Our sets of experiments clearly showed that an increase in dissolved compounds such as DOC negatively affects $O$. naumanni (Fig. 6). However, addition of inorganic nutrients (macro- and micronutrients included in $\mathrm{MBL}$ culture medium) did not have an effect, either positively or negatively, on $O$. naumanni growth rates (Fig. 7). The ultimate reason why an increase in DOC concentration affects $O$. naumanni is not clear. Probably, this limitation to low DOC concentration is a consequence of the adaptation of $O$. naumanni to such poor and unproductive environments as Lake Moreno Oeste. In our set of experiments we explored the possible acclimatisation of O. naumanni to higher concentrations of dissolved compounds (Table 1, Expts 4 and 8). However, after 6 or $8 \mathrm{~d}$ (which implied 3 to 50 . naumanni generations), negative growth rates were still obtained. Perhaps $O$. naumanni adaptation to ultraoligotrophic conditions is associated with its large size. This would be supporied by the fact that Stentor araucanus, which is also large, has a similar lake distribution (Geller et al. 1996, Modenutti 1997). Large-sized ciliates have lower metabolism per body mass, and lower growth rates than smaller ones (Fenchel 1987). Unfortunately, we do not know how size and DOC concentration would be coupled in these large mixotrophic ciliates.

The idea that ciliate communities are related to limnological features is not new. Based on a data set from 20 North American lakes in Florida, Beaver \& Crisman $(1982,1989)$ related the community structure of ciliated protozoa to lake productivity. According to this study, a compositional shift occurs from oligotrophic lakes dominated by Oligotrichida to eutrophic assemblages codominated by Scuticociliatida, Oligotrichida and Haptorida. In addition, large-bodied ciliates (40 to $50 \mu \mathrm{m}$ ) were progressively replaced by small-bodied ciliates $(20$ to $30 \mu \mathrm{m})$. The observed shifts occur as a consequence of changes in quality and quantity of food. Small-bodied $(<30 \mu \mathrm{m})$ bacterivorous taxa that dominate eutrophic lakes are reduced in oligotrophic ones where bacteria concentrations are limiting and are replaced by those larger-bodied taxa $(>30 \mu \mathrm{m})$ able to ingest nanoplanktonic algae in addition to bacteria (Beaver \& Crisman 1982). Within the latter, a number of mixotrophic taxa (Pelagohalteria viridis (Fromentel), Askenasia chlorelligera Krainer \& Foissner, among others) feeding particularly upon nanoplankton are included (Beaver \& Crisman 1989, Macek et al. 1996).

In Lake Morenito a ciliate community dominated by oligotrichs and prostomate holotrichs, including mixotrophic species, resembles that of oligotrophic lakes as described by Beaver \& Crisman (1989) and Macek et al. (1996). Food conditions (phytoplankton and bacteria cell abundances) for algivorous and bacterivorous ciliates are improved in this lake in comparison with the ultraoligotrophic Lake Moreno Oeste. Thus, the taxa registered in Lake Morenito are mainly mixotrophic species (Strombidium viridae, Askenasia sp. 
and Pelagohalteria sp.), and algivorous raptorial species (Balanion planctonicum, Urotricha spp.) which feed upon nanoflagellates such as Rhodomonas (Müller 1991, Müller et al. 1991).

The ciliate size pattern suggested for the oligotrophic-eutrophic transition can be widened when ultraoligotrophic lakes of the southern hemisphere are included. Ciliate size continues increasing in larger (>80 $\mu \mathrm{m}$ ) mixotrophic species. In this range, from oligotrophic to ultraoligotrophic conditions, the dissolved fraction probably plays an important role in Ophrydium naumanni distribution. Our results support this hypothesis since highly negative growth rates were obtained when $O$. naumanni was reared in filtered water with higher dissolved compounds concentration like Lake Morenito water.

Acknowledgements. Thanks to Dr Donald Morris, Lehigh University, Pennsylvania, for DOC determination and supply of low carbon pure water. Thanks also to an anonymous reviewer whose comments greatly improved the manuscript. This work was supported by FONCYT PICT 01-00000-01194 and CONICET-PIP 0739/98.

\section{LITERATURE CITED}

Amblard C, Sime-Ngando T, Rachiq S, Bourdier G (1993) Importance of ciliated protozoa in relation to the bacterial and phytoplanktonic biomass in an oligo-mesotrophic lake, during the spring diatom bloom. Aquat Sci 55:1-9

APHA (American Public Health Association) (1985) Standard methods for the examination of water, sewage, and wastewater, 16th edn. American Public Health Association, Washington, DC

Beaver JR, Crisman TL (1982) The trophic response of ciliated protozoans in freshwater lakes. Limnol Oceanogr 27 : $246-253$

Beaver JR, Crisman TL (1989) The role of ciliated protozoa in pelagic freshwater ecosystems. Microb Ecol 17:111-136

Fenchel T (1987) Ecology of Protozoa. The biology of free-living phagotrophic protists. Springer-Verlag, New York

Foissner W, Wölfl S (1994) Revision of the genus Stentor Oken (Protozoa, Ciliophora) and description of S. araucanus nov. spec. from South American lakes. J Plankton Res 16: $255-289$

Foissner W, Blatterer H, Berger H, Kohmann F (1991) Taxonomische und ökologische revision der Ciliaten des Saprobiensystems, Band I. Cyrtophorida, Oligotrichida, Hypotrichia, Colpodea. Informationsberichte des Bayerischen Landesamtes für Wasserwirtschaft, München, Heft $1 / 91$

Foissner W, Berger H, Kohmann F (1992) Taxonomische und ökologische revision der Ciliaten des Saprobiensystems, Band II. Peritrichia, Heterotrichida, Odontostomatida. Informationsberichte des Bayerischen Landesamtes für Wasserwirtschaft, München, Heft 5/92

Foissner W, Berger H, Kohmann F (1994) Taxonomische und ökologische revision der Ciliaten des Saprobiensystems, Band III. Hymenostomata, Prostomatida, Nassulida. Informationsberichte des Bayerischen Landesamtes für Wasserwirtschaft, München, Heft 1/94
Foissner W, Blatterer H, Berger H, Kohmann F (1995) Taxonomische und ökologische Revision der Ciliaten des Saprobiensystems, Band IV. Gymnostomatea, Loxodes, Suctoria. Informationsberichte des Bayerischen Landesamtes für Wasserwirtschaft, München, Heft 1/95

Geller W, Gaedke U, Barthelmeß T, Lang M, Straile D, Wölfl $S$ (1996) Comparative limnology of the planktonic system on subalpine and subandine lakes. 11 Congr. Assoc Ital Oceanol Limnol 79-90

Jones R (1994) Mixotrophy in planktonic protists as a spectrum of nutritional strategies. Mar Microb Food Webs 8 : $87-96$

Macek M, Śimek K, Pernthaler J, Vyhnalek V, Psenner R (1996) Growth rates of dominant planktonic ciliates in two freshwater bodies of different trophic degree. J Plankton Res 18:463-481

Modenutti BE (1997) Distribución de los ciliados planctónicos Ophrydium naumanni y Stentor araucanus en lagos oligotróficos Andinos. Rev Soc Mex Hist Nat 47:79-83

Modenutti BE, Balseiro EG, Moeller R (1998d) Vertical distribution and resistance to ultraviolet radiation of a planktonic ciliate Stentor araucanus. Verh Int Ver Limnol 26: $1636-1640$

Madenutti BE, Balseiro EG, Queimaliños CP, Añón Suárez D, Diéguez MC, Albariño RJ (1998b) Structure and dynamics of food web in Andean lakes. Lake Reservoir Manag 3: $179-186$

Morris DP, Zagarese HE, Williamson CE, Balseiro EG, Hargreaves BR, Modenutti BE, Moeller R, Queimaliños C (1995) The attenuation of UV radiation in lakes and the role of dissolved organic carbon. Limnol Oceanogr 40:1381-1391

Müller H (1991) Pseudobalanion planctonicum (Ciliophora, Prostomatida): ecological significance of an algivorous nanociliate in a deep meso-eutrophic lake. J Plankton Res 13:247-262

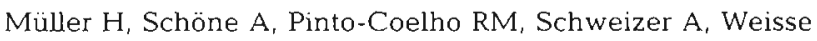
$T$ (1991) Seasonal succession of ciliates in Lake Constance. Microb Ecol 21:119-138

Nichols HW (1973) Growth media-freshwater. JR Stein Handbook of phycological methods. Cambridge University Press, New York, p 7-24

Nygaard K, Tobiesen A (1993) Bacterivory in algae: a survival strategy during nutrient limitation. Limnol Oceanogr 38 : 273-279

Pejler B (1962) Notes on some limnoplanktic protozoans with descriptions of two new species. Zool Bidr Upps 33: $447-452$

Perris SJ, Laybourn-Parry J, Jones RI (1994) Chlorophyll contents and photosynthetic rates of the freshwater mixotrophic ciliate Strombidium viride (Ciliophora, Oligotrichida). Arch Hydrobiol 130:473-483

Porter KG, Feig YS (1980) The use of DAPI for identifying and counting aquatic microflora. Limnol Oceanogr 25:943-948

Queimaliños CP, Modenutti BE, Balseiro EG (1999) Symbiotic association of the ciliate Ophrydium naumanni with Chlorella causing a deep chlorophyll a maximum in an oligotrophic South Andes lake. J Plankton Res 21:167-178

Reisser W, Meier R, Gortz HD, Jeon KW (1985) Establishment, maintenance, and integration mechanisms of endosymbionts in Protozoa. J Protozool 32:383-390

Stoecker DK, Silver MW (1987) Chloroplast retention by marine planktonic ciliates. Ann NY Acad Sci 503:562-565

Wölfl S (1995) Untersuchungen zur Zooplanktonstruktur einschließlich der mikrobiellen Gruppen unter besonderer Berücksichtigung der mixotrophen Cilliaten in zwei südchilenischen Andenfußseen. Doctoral thesis, Universität Konstanz 